\title{
Students' research on lean and green
}

\author{
Itziar Lujan-Blanco \\ Ph.D. candidate - EMRN Natural resources program \\ Universitat Politecnica de Catalunya-BarcelonaTech \\ Manresa (Barcelona), Spain \\ itziar.lujan@upc.edu
}

\author{
Jordi Fortuny-Santos \\ Business Management Department \\ Universitat Politecnica de Catalunya-BarcelonaTech \\ Manresa (Barcelona), Spain \\ jordi.fortuny@upc.edu
}

\begin{abstract}
This paper reports on the contribution of students to a research project. Its distinct characteristics are the relation between teaching and research, the early involvement of undergraduate students in research and the aim of raising students' environmental awareness. A group of students taking a compulsory course on Operations Management were asked to survey companies on the existence of synergic relations between lean manufacturing and environmental performance, which is the research topic of a Ph.D. candidate. The research began with the design of a structured questionnaire. The students interviewed operations managers in manufacturing companies. Since this subject is part of a blended learning program in engineering, many students already work in companies and interviewing their managers allowed them to gain a different view of the firm's activities. The results of the experience show the total involvement of the students. They learnt about lean manufacturing practices and about environmental issues. The study showed the relation between "lean" and "green" topics.
\end{abstract}

Keywords-Inquiry-based learning; lean manufacturing; Teaching-research nexus; undergraduate research.

\section{INTRODUCTION}

In industrial countries, companies are forced to comply with regulations related to air and water emissions, and the handling and disposal of waste. Regulations shape the processes and products and besides, compliance with these requirements may cost millions of dollars. Over that past years there has been a growing recognition that the relationship between manufacturing performance and environmental performance is complex. On one hand, resource conservation and waste prevention helps to reduce costs and liabilities. It is good for both the bottom line and the natural environment. On the other hand, the field of manufacturing has experienced the introduction of advanced manufacturing strategies, such as lean management. Studies such as those in "the Machine that Changed the World" [1] evidenced a shift towards these new manufacturing strategies, focusing on reducing waste in the manufacturing process. Some researchers have suggested there is a positive correlation between environmental performance and profit, cost or quality [2]. In addition, several researchers have argued that those firms adopting higher performing advance manufacturing strategies, such as lean production, will also have superior environmental performance [3], [4], [5].
A group of 30 students of Engineering taking a course on Operations Management at the School of Engineering of the Technical University of Catalonia at Manresa (EPSEM) were asked to survey Catalan companies to find out whether there is a synergic relation between lean manufacturing, a key concept of Operations Management, based on the elimination of waste, and being green (having superior environmental performance). While the course is based on the tools of lean manufacturing, students do not know much about environmental topics. The topic was chosen because the relation between "lean" and "green" was the research subject of a doctoral candidate of the school and because the school was implementing an environmental management system at that time, so it was necessary to raise everybody's awareness on environmental issues. With this experience, students get involved in research and gain knowledge from direct observation from industry. These students are in a blended learning program (which combines presence-based and virtual modes) which presents important advantages for implementing experiences, like the one described here, that require active learning. The pedagogical methods this experience is based on are constructivism (people learn by interaction) and inquiry-based learning (undergraduate students start doing research). Inquiry-based learning supports the aims of the Bologna process [6] and national governments that claim the integration of research in curricula at the undergraduate level. In this paper we are interested in understanding the properties and value of this resource for engineering educators. The overall conclusion is that student involvement promotes positive attitudes and academic achievement.

\section{REVIEW OF LITERATURE}

\section{A. Inquiry-based learning, the link between research and teaching}

A bibliometric study [7] reveals that $62.2 \%$ of the 45 main journals on Operations Management have never published a paper on research on teaching innovation in Operations Management (between 1995 and 2010). The remaining 17 journals have only devoted a $0.4 \%$ of their content to teaching innovation. The evident conclusion is that there is a dearth of research if compared to other subjects such as marketing or accounting. 
However, innovation in teaching strategies is necessary to improve the learning process in order to ensure that students of engineering, at graduation time, will have the required skills for their professional career. In consequence it is necessary to conduct research in teaching and learning methods [8], especially because [7]:

Many students seem less interested in Operations Management than in other subjects. [9].

In the European context, the Bologna process asks for new teaching methods that focus on the learner, not on the lecturer, where students play an active role [10].

As a response to the call above, in this paper, we analyze an experience of inquiry-based learning in a course of Operations Management aiming at identifying and disseminating a practice that effectively integrates teaching and research and allows students to extend their understanding of course contents and discover "new knowledge" following a natural learning [11]. Finally, we draw conclusions on the applicability of the method and its results. In the following lines we try to find support from our experience from two points of view: the academic one (previous research on the pedagogical issues of the method) and the political one (legal aspects that reinforce our experiment).

While for many faculty members research and teaching are uncorrelated activities [12, 13], Colbeck [14] found faculty members that successfully integrated teaching and research: they engage in activities that accomplish research and teaching goals at the same time. This can be done in many ways. For example, [14] mentions the case of a professor who analyzed with his students the research papers he was reviewing for a journal. In this paper, we analyze a case of integration of research and teaching consisting in the experience of a group of undergraduate students doing research on the relations between a topic in the syllabus of the course and another topic not in the syllabus but very important in engineering.

The theoretical basis of this paper is termed inquirybased learning. "Inquiry" can be defined as seeking knowledge/information through questioning. Therefore, it entails some sort of research. By Inquiry -based learning we refer to an instructional model that centers learning on an investigation conducted by undergraduate students that makes an original contribution to the discipline.

Inquiry-based learning is not just asking questions, but it is a way of converting data into useful knowledge (the way babies and children do to get to understand their world) which needs an understanding of how to make sense out of such information.

The pedagogical method inquiry-based learning finds its guiding philosophical principle in constructivism, a widely used approach in teaching and learning, and particularly in the learning theories of Piaget (Theory of Cognitive Development) and Vygotsky (Sociocultural Theory). Constructivism explains how learners achieve or "construct" knowledge: it is assumed that people are active learners and knowledge is built from the interaction with people and situations [15]. In consequence, learning is not an outcome but a process, and namely a continuous process of adaptation to the world and creation of knowledge, grounded in experience [16]

To have full understanding of a topic, it is necessary to have meaningful knowledge of it. If knowledge is built upon experience [16], the theoretical training is not enough: experiencing and making sure that an idea is applicable to real life is essential [17].

As [18] point out, if there is a link between research and teaching, it operates through that which they have in common: the act of learning. In consequence, the link can be exploited further in the design of courses that emphasize the collaboration between lecturers/researchers and undergraduate students. The research project in our case is a good example of such collaboration.

Going back to Kolb's experiential learning theory [16], effective learning is achieved through a cycle of four stages: (1) concrete experience, (2) reflective observation of the experience; (3) abstract conceptualization (the analysis of the prior point leads to formation of abstract concepts and general conclusions); (4) active experimentation (the learner applies the knowledge to test hypothesis in future situations, resulting in new experiences). For example, a type of experiential technique which fulfils the previous stages, often used in business and operations management courses, is simulation [19]. To be effective, our inquiry-based learning case must reinforce Kolb's cycle too.

In fact, there are several different inquiry-based learning models. The simplest type, addressed to younger learners, consists in requesting the students to make questions about a given theme based on a text proposed by teachers. After reading the text, the students are asked to create questions that are shared among students [20]. Project-based learning (PBL), a learning approach widely used in engineering education, can be considered a type of inquiry -based learning which allows the students to learn via applying knowledge learned in class to solve well-design problems that represent real-world scenarios. [11]

According to the National Academy of Sciences (United States of America) [cited in 21], when students learn through inquiry, they ask questions (to themselves); investigate; use evidence (data) to describe, explain, and predict; connect evidence to knowledge; and share findings with their mates. The previous steps describe the natural process the learners follow when seeking answers and deeper understanding and they closely follow Kolb's cycle and even the scientific method [21].

Unluckily, traditional methods of teaching and assessing students are used to may discourage the process of inquiry: Students are expected to listen and repeat the expected answers. However, in our university, even students claim that, since their lecturers are leaders in their research fields, it would be very interesting for students to "taste" what the lecturers are working on (maybe at a less difficult level). They think that that would motivate both the students and the researchers. In literature, we find that obviously not all students are of the same opinion: some think that the "old way" is easier for them, at least in the short run. In 
consequence, the implementation of new techniques requires clear explanation in order to drive out fear and motivate students. In our case, students were motivated.

Inquiry-based research requires a change in the students' mentality but, in order to promote student involvement in research, it is necessary to make changes in teaching in a way that teaching and research are related $[22,23]$ including detailed planning of student participation and formal assessment of students' research activities. It conveys a change in the role of the professors: They move from being lecturers to tutors that establish the tasks and support or facilitate the process, but the students pursue their own lines of enquiry, draw on their existing knowledge and identify the consequent learning needs [24]. In our case, lecturers were interested in new teaching and learning approaches and they were willing to try this experience.

Any lecturer may create such learning opportunities, but especially a person who is still an active researcher because he/she can show the students the real methods that are used in research and which are the current issues research focuses on. In consequence, the process contributes to develop students' understanding of the role of research in their discipline, develop students' abilities to do research, and progressively develop students' understanding [25]. Undergraduate students can grasp knowledge and even help to create knowledge. Eventually, inquiry-based learning is about involving the learners and leading them to understand.

In [26]) four ways of engaging undergraduates with research and inquiry are identified: (i) research-led: learning about current research in the discipline; (ii) research-oriented: developing research skills and techniques; (iii) research-based: undertaking research and inquiry; (iv) research-tutored: engaging in research discussions. This model has two axes: one classifies the ways students may be engaged in research and inquiry, while the other axis classifies the research approach as content-focused or process-focused). Our experience corresponds to the third type.

Reference [18] states that undergraduate research and inquiry can be based on 'commonly known' topics (but new to the students), 'commonly unknown' topics (new to the students and many lecturers, except those doing research on that particular topic) or even on 'totally unknown' topics (new to the students and lecturers). In our case, the research on lean manufacturing can be considered as "commonly known" but the link between lean manufacturing and environmental performance, although it is not new, is rather unknown.

Linking teaching and research is not a new question. In 1810, Von Humboldt said that universities should find new models that were able to develop students' skills of inquiry and research [cited in 26]. In present times, there is a growing consensus around the need for undergraduate research and inquiry, grounded in the argument that when students graduate they have to be well prepared for today's society with skills that are developed particularly well through research and inquiry-based learning opportunities [27].

Healey and Jenkins [26] contend that universities should support research (and enquiry) based learning. They argue that all undergraduates should experience learning through, and about, research like academic researchers do. The method has proved its effectiveness in encouraging engineering students begin a Ph.D. program [28, 29].

However, the problem has not been well solved. Brew [30] examines existing models and different ways of understanding undergraduate research to argue that there is a need for a coherent framework for student research.

In the Europe Union, each country has its own national higher education system, that is being reshaped by the Bologna process (harmonization of the bachelors and masters level education across countries) to create the European Higher Education Area (EHEA). The success of European countries depended upon natural resources and labor in the past, but the future depends on intellectual capital (valueadded research and innovation)

As an example, attention has been given in the UK on how Research-Teaching Linkages can be achieved [31] and used to enhance graduate attributes or higher order skills such as critical thinking, analysis and problem solving, and especially those related to employability such as understanding, skilful practices, efficacy beliefs and metacognition [32].

Literature reports that the expected benefits of undergraduate research include [33] increased confidence, cognitive and technical skill development, problem-solving and critical thinking development, clarification of future career or educational opportunities, an understanding of how knowledge is created, and increased understanding of disciplinary ways of thinking and practicing. Students learn to be critical thinkers and not to be passive consumers of information but creative contributors. These attitudes are important for the future students' professions [34]. On the basis of previous research and our own experience, we contend that this model brings significant benefits to individual student learners, universities and in consequence to society.

\section{B. Blended learning}

Blended Learning has gained considerable interest in recent years as an environment for supporting learning and teaching. Blended learning is the combination of distant learning and face to face instruction. This definition indicates that the blended learning is an opportunity to use synchronous and asynchronous tools including online resources (e-learning) to support traditional teaching methods. There are only 20 hours for class meetings so the students have to work by themselves in most of the time. The best way to achieve the course requirements is to use the constructivist approach and let the students work with and build the required knowledge and skills gradually [35]. Reference [36] states that Engineering students focus too much on Math, while current society wants them to be able to work in group and solve problems in a creative way, which are generic interdisciplinary skills. Authors suggest that blending learning provides an environment to support students' thinking powers through creative problem solving. In this paper, the problem that 
students have to solve is the relation between lean and green. It requires active learning: students have to visit companies and interview their managers and that takes time. Therefore it might not be a good activity for courses where students spend all day in the classroom, but it is perfect for a course where students only spend two evenings at university and study at home.

\section{Lean manufacturing}

For the purpose of this study we can define lean manufacturing as a set of synergistic work practices that focus on the systematic reduction of waste and non-value added activities from a firm's manufacturing operations [37]. A list of tools and techniques of lean manufacturing includes total quality management, production adjusted to demand, onepiece flow, total preventative maintenance, pull flow, quick changeovers, controlled processes, involved cross-trained employees and continuous improvement [38], [39]. Although lean manufacturing emerges from the Toyota Production System [40], also known as just-in-time, today the fundamentals of lean thinking are successfully applied in hospitals, building, retail, and other services that aim at being efficient (i.e. avoid wasting resources such as labor, raw materials, energy, floor space...).

\section{Universities and the environment}

Since the Industrial Revolution, the impact of mankind on Earth has increased dramatically. The search for natural resources and the industrialization have damaged the environment. Today's society is becoming aware of problems like water scarcity, global warming and climate change and such environmental problems are so serious that companies must take them into account their impact on the environment in their ordinary activities [41], [42]. Companies have to meet the expectations of their stakeholders and currently, these expectations include environmental issues.

Besides manufacturing companies, the ideas above are valid for any type of organization, including universities. Furthermore, universities have the special characteristic that their activity can have positive impacts on the environment, such as the consequences that training can have on the state of awareness and responsibility towards the environment of future professionals and the possible generation of knowledge oriented to the reduction of impacts on the environment [43]. Universities around the world have undertaken practices such as recycling and reducing consumption of energy and water, [44].

Reference [45] explains the pedagogical effects of "greening" a university because universities teach and demonstrate the methods and consequences of environmental management to their students, while raising environmental awareness. The World Summit on Sustainable Development in Johannesburg in 2002 formally recognized education as a key mechanism for promoting environmental protection and conservation and stressed that education should help society to achieve higher levels of sustainability [46].
Educational programs instill environmental awareness by different means [47]: the Technical University of Catalonia (UPC) approved its first environmental plan in 1996. The plan included the introduction of environmental topics in all the subjects and the promotion of research on environmental issues [48]. In 2004, the University decided to implement an environmental management system, according to the European Eco-Management and Audit Scheme (EMAS), in two of its campuses, being one of them the School of Engineering at Manresa (EPSEM). The reason may be that the school has always shown great interest in environmental topics in its research. The excellence doctoral program in natural resources and the environment is a proof of this interest.

\section{METHODOLOGY}

This experience is based on the combination of four items:

(i) There is a doctoral candidate at the EPSEM who needs to do some field work in order to collect data for her dissertation about the relations between "lean" and "green". This research task usually takes a lot of time. Furthermore, in Spain, academic surveys do not reach a high level of participation (real figures are between ten and twenty percent).

(ii) EPSEM offers every year an advanced course on operations management that focuses on lean manufacturing as part of a blended learning program in engineering. It is interesting for the students to see in place the tools and techniques of lean manufacturing and learning the pros and cons of this philosophy.

(iii) The School is committed to positively protecting the environment and therefore all subjects must include environmental topics. This should help increase engagement of students with the environment and sustainability [49] and better prepare them for technically fulfilling the legal and social requirements related to environmental performance [50].

(iv) In order to improve academic excellence and improve the research activity of the country, the Bologna process encourages student early involvement in research.

We thought that if students might participate in research design, execution, analysis and writing, it would be an effective means of providing students with practical research experience while overcoming the difficulty of engaging the interest of students in a subject which may not be appealing [51].

The aim of the research project was to respond to four hypotheses:

- Hypothesis 1: Industrial Catalan companies are unaware of the philosophy, techniques and practices of lean manufacturing even though some characteristics of the processes and the features of the products support some of the principles of lean manufacturing.

- Hypothesis 2: Companies apply the concept of value in the development of processes, although they are unaware of the term. 
- Hypothesis 3: The adoption of standard processes, environmental practices and traceability helps reduce the complexity in product and process variation.

- Hypothesis 4: In Catalan companies, people are a key resource and they are involved in process improvement.

Research started with learning about lean manufacturing (it is the content of the course) and the environment (in an attempt to "green" the subject). The second step was the design of a questionnaire. This step is the key to collect primary data. The final version of the questionnaire included 32 questions that refer to operations analysis in lean companies and environmental management. Some of the questions can be quickly answered by means of a four-point Likert scale, while others are open questions. The third step was to conduct the survey through structured personal interviews. Each student visited a company and therefore the sample consists of 30 valid questionnaires because that was the number of students enrolled in the course. The final step of the process was the statistical analysis of the data. A campus licensed version of Minitab v.15 was used for that purpose.

\section{RESULTS AND DISCUSSION}

In this study, students observed that many companies did not know much about the techniques and tools of lean manufacturing. Only in larger companies some techniques and practices were detected. However, broadly speaking, companies were aware that certain tasks or activities just add cost to the product and therefore their reduction is necessary.

Lean philosophy offers a systematic way of eliminating waste (operations that do not add value to the product). Value is what the customer is willing to pay for so waste can be explained as anything that adds cost to the product and the customer is unwilling to pay. Therefore lean manufacturing can bring a reduction in the total cost of the product. Ohno [52] identifies seven types of waste (Fig. 1):

- Overproduction (Energy, material and labor devoted to manufacturing products that no-one will buy and may end in the landfill).

- Excess inventory (as in the previous case, resources devoted to materials that are not necessary and may end in the landfill).

- Waiting time (Time and energy lost waiting).

- Unnecessary transportation (Time and energy lost. It may damage the product).

- Over-processing (unnecessary operations that waste material, energy and labor).

- Motion (unnecessary operations that represent a waste of labor and can be unhealthy for the operator).

- Defects or lack of quality (Energy, material and labor devoted to manufacturing products that cannot be sold and may end in the landfill or require extra resources to be repaired).

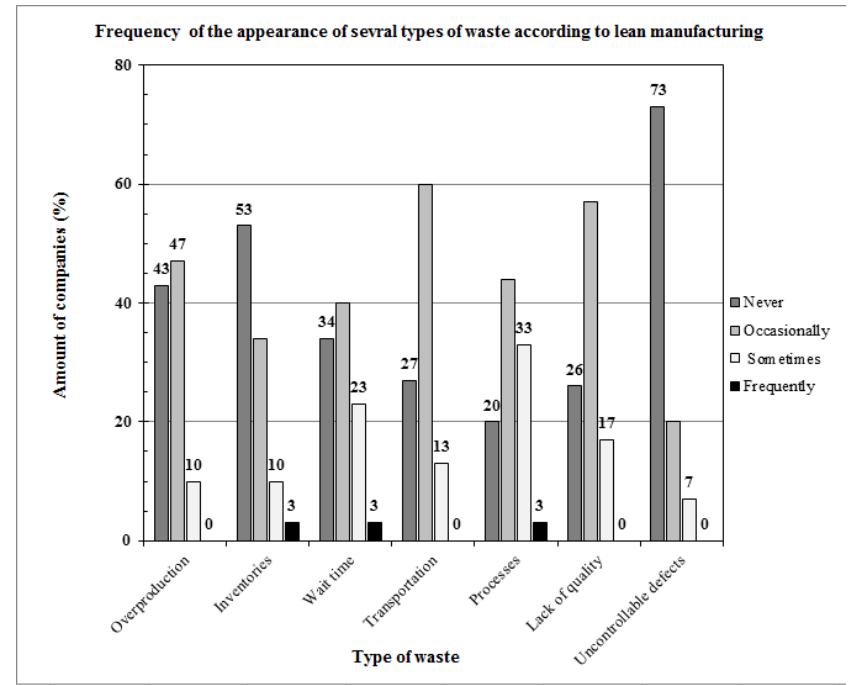

Fig. 1. Different types of waste in the companies in the sample

Students identified how often the companies faced the different types of waste:

- Overproduction. $46.7 \%$ of the companies stated that they occasionally suffer from overproduction and $10 \%$ sometimes. $43.3 \%$ of the surveyed companies stated that this situation did never happen. No-one answered that this was a frequent problem.

- Excess raw-material inventory. $33.3 \%$ of the companies stated that they occasionally experience excess inventory and $10 \%$ sometimes. $53 \%$ of the companies stated that this situation did never happen. $3 \%$ answered that this was a frequent problem.

- Wait time appears occasionally in $40 \%$ of the cases and often in $23.3 \%$. $33.3 \%$ answered that they never experienced this situation and $3.3 \%$ reported frequent wait time.

- Long Transport: $26.7 \%$ of the surveyed companies considered that they never faced such situation. $60 \%$ did so occasionally and $13.3 \%$ sometimes.

- Inadequate processing and motion occasionally appears in $43.3 \%$ of cases, often in $33.3 \%$ and never in $20 \%$. $3.3 \%$ answered that this was a frequent problem.

- Lack of product quality: $26.7 \%$ of companies never reached this situation, $56.7 \%$ did so occasionally and $16.7 \%$ often, although $20 \%$ of the companies occasionally experience uncontrollable defects and $6.7 \%$ sometimes.

These answers supported the first hypothesis.

The theoretical concept of value analysis, in general, was unclear among companies, but they used its logic to avoid the appearance of different forms of waste. Although a high percentage of companies do not know about it, they thought that implementing it would be a good idea. Through open comments, the students detected how companies avoided the 
operations or processes that did not add value to the product. These answers supported the second hypothesis.

Since proper environmental management is essential in lean production (to avoid waste), the survey asked companies whether they had a written environmental policy (Fig. 2) and whether they had an environmental officer (Fig. 3). On one hand, $56.7 \%$ companies had a written environmental policy and $16.7 \%$ were implementing it (usually in the form of an environmental management system according to ISO 14001 standard). On the other hand, 53\% of companies in the sample had an environmental officer. In $40 \%$ of the cases, the environmental manager was also the occupational safety and health officer.

A $90 \%$ of the surveyed companies confirmed they managed the environmental issues and nearly $100 \%$ had a traceability system in place. Since environmental management standards and traceability requirements help reduce the complexity of products and processes, we have evidences that support the third hypothesis.

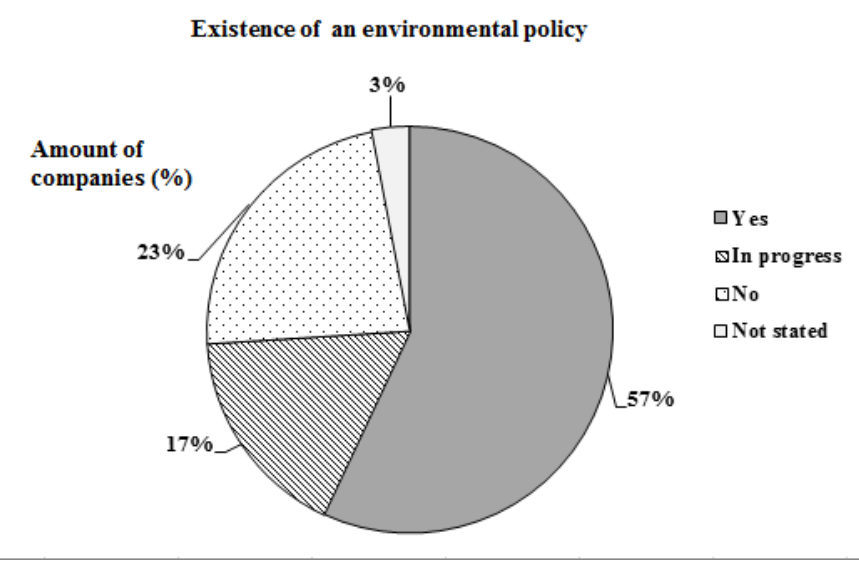

Fig. 2. Existence of an environmental policy in the surveyed companies

\section{Existence of an environmental office}

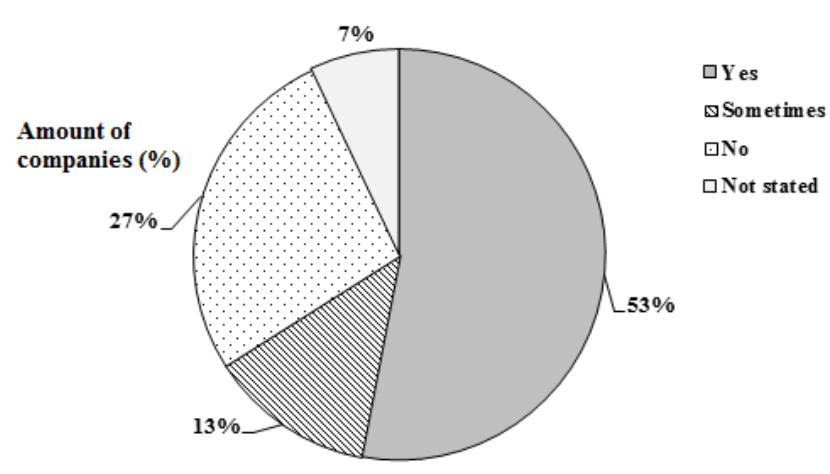

Fig. 3. Existence of an environmental officer in the surveyed companies
The importance of people in the company was measured through the way workers are involved in continuous improvement. Many companies claimed that worker empowerment was not possible because workers were not adequately trained and turnover figures were too high. These answers do not support the fourth hypothesis.

However, a $53.3 \%$ admitted that workers took part in continuous improvement activities. When questioned about how the company managed workers' suggestions (Fig. 4), $20 \%$ of the companies stated that employees should communicate with the line supervisor (20\%). 23.3\% stated that the employees should report to the manager. $26.7 \%$ has continuous improvement teams and $30 \%$ had written procedures on non-conformities that employees should follow.

\section{V.CONCLUSIONS}

The Technical University of Catalonia-BarcelonaTech is concerned about environmental issues and therefore tries to green their campuses. The School of Engineering at Manresa is especially interested on preserving the environment and involving everyone in that task. On one hand, that means, amongst other requisites, that topics about the environment, pollution, and so on, should be studied within as many subjects as possible, in order to increase students' environmental awareness. Besides, there should be research on environmental issues. These aspects have been included in an environmental management system in order to monitor their achievement. On the other hand, students should be early involved in research.

For the reasons above, a group of 30 students taking a course on Operations Management were asked to survey Catalan companies on the existence of synergic relations between lean manufacturing and environmental performance.

Although the sample was limited, the study showed the relation between "lean" and "green".

After completing the assignment, the research process was assessed. All the students took part in this experience, even though the assignment was not compulsory and they knew that they would not get extra marks for this activity.

Management of workers's suggestions (improvement ideas)

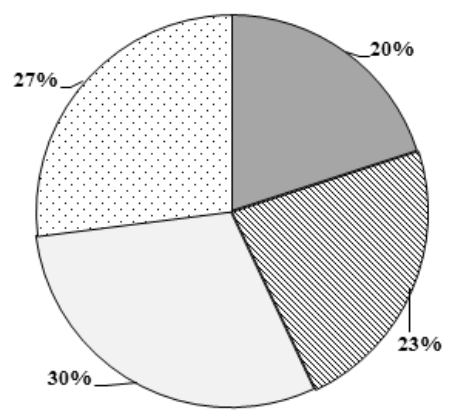

Amount of companies (\%)

$\square$ Line superv isor ه $\mathrm{M}$ anager $\square$ Non-conformity p roced ure amp ror ement teams

Fig. 4. Management of worker's suggestions or improvement ideas in the companies in the sample 
They admitted that they had learnt more about lean manufacturing practices and about environmental management than they would have learnt in the classroom. They stated that they knew a little bit more about research because they only knew the teaching face of university. They enjoyed the experience of talking to managers in companies.

The perceptions of the students were collected on a questionnaire. Responses showed the total involvement of the students, their favorable attitudes and their academic achievement. Students admitted that they had had the chance to compare in-class theory with real world practice. They had seen how companies implement, use and benefit from the tools they learn in the classroom. They also collected negative opinions on certain issues so they could compare different views, and had the chance to reflect on them (so they learned following Kolb's cycle). As stated by Neumann [53], inquiry-based learning increased the course' credibility and the perception that students were learning relevant and current course content.

In consequence, this paper makes a contribution to engineering education by providing a tool that can be used to promote student true learning, beyond memorization, and increase student motivation as it has been empirically confirmed. It does not offer new theories but it contributes to the establishment and deeper understanding of existing ones. It is recommended that inquiry-based instruction be utilized in the classroom, as often as is practical.

\section{References}

[1] J.P. Womack, T. Daniel and D. Ross, The machine that changed the world. New York: Rawson associates, 1990.

[2] M.E. Porter and C. Van der Linde, "Toward a new conception of environment competitiveness relationship," J. Economic Perspectives, vol. 9, issue 4, pp 97-118.

[3] S. Rothenberg, Is lean green? The relationship between manufacturing processes and environmental performance within different regulatory contexts. Doctoral Thesis. Cambridge: Massachusetts Institute of Technology, 1999.

[4] R. Florida, "Lean and green: The move to environmentally conscious manufacturing," California manufacturing review, vol. 39, issue 1, pp. 81-105, 1996.

[5] G. Miller, J. Pawloski, and Ch. Standridge, "A case study of lean, sustainable manufacturing," J. of Industrial Engineering and Management, vol. 3, issue 1, pp. 11-32, 2010.

[6] Conference of European Ministers Responsible for Higher Education, The Bologna Process 2020 - The European Higher Education Area in the new decade. Communiqué of the Conference of European Ministers Responsible for Higher Education, Leuven 28-29 April 2009. (online), URL http://www.ehea.info/Uploads/Declarations/Leuven_Louvain-laNeuve_Communiqué_April_2009.pdf, [Accessed July 7, 2014], 2009.

[7] C. Medina-López, R. Alfalla-Luque and J.A. Marin-Garcia, " Research in operations management teaching: Trends and challenges," Intangible Capital, vol 7, issue 2, pp. 507-548, 2011.

[8] A.Y. Kolb and D.A. Kolb, "Learning Styles and Learning Spaces: Enhancing Experiential Learning in Higher Education," Academy of Management Learning \& Education, vol. 4, issue 2, pp. 193-212, 2005.

[9] K. Desai and R. A. Inman, "Student Bias against POM Coursework and Manufacturing", Int. J. Op. \& Prod. Mng. vol. 14, issue 8, pp.70-87, 1994.

[10] Coimbra Group of Universities, European Union Policies and Strategic Change for e-learning in Universities, Report of the Project "Higher
Education Consultation in Technologies of Information and Communication” (HECTIC). Brussels: European Commission, 2002.

[11] J. Dong and H. Guo, "Effective Collaborative Inquiry-based Learning in Undergraduate Computer Networking Curriculum," $120^{\text {th }}$ ASEE Annual Conference \& Exposition of the American Society for Engineering Education held in Atlanta, June 23-26, 2013, (online), URL: http://www.asee.org/public/conferences/20/papers/6113/view, [Accessed July 7, 2014], 2013.

[12] R. Ramsden and I. Moses, "Associations between research and teaching in Australian higher education," Higher Education, vol. 23, issue 3, pp. 273-295, 1992.

[13] H.W. Marsh and J. Hattie, "The relation between research productivity and teaching effectiveness-Complementary, antagonistic, or independent constructs?," J. Higher Education, vol. 73, issue 5, pp. 603-641, 2002.

[14] C.L. Colbeck, "Merging in a Seamless Blend: How Faculty Integrate Teaching and Research," J. Higher Education, vol. 69, issue 6, pp. 647671, 1998.

[15] D.H. Schunk, Learning theories: An educational perspective (6th ed.). Boston, MA: Pearson Education, 2012.

[16] D.A. Kolb, Experiential learning: experience as the source of learning and development. Englewood Cliffs, NJ: Prentice Hall, 1984.

[17] M. Lewis and H. Maylor, "Game playing and operations management education, “. Int. J. Prod. Econ. Vol. 105, issue 1, pp. 134-149, 2007.

[18] A. Brew and D. Boud, "Teaching and research: establishing the vital link with learning," Higher Education, vol. 29, issue 3, pp. 261-273, 1995.

[19] H. Haapasalo and J. Hyvönen "Simulating business and operations management - a learning environment for the electronics industry ," Int. J. Prod. Econ. Vol. 73, issue 3, pp. 261-272, 2001.

[20] D. Epstein, I. da Costa Pinho, O. Costa Acosta and E.. Reategui, "Inquiry-based learning environment using intelligent tutoring system," 2013 IEEE Frontiers in Education Conference (FIE 2013). Proceedings of a meeting held 23-26 October 2013, Oklahoma City, Oklahoma, USA. Institute of Electrical and Electronics Engineers (IEEE), pp. 10721074, 2013.

[21] A. J. Warner and B. E. Myers, What Is Inquiry-Based Instruction?, Document AEC394. Department of Agricultural Education and Communication, University of Florida / Institute of Food and Agricultural Science Extension. (online) URL: http://edis.ifas.ufl.edu, [Accessed July 7, 2014], 2014.

[22] B.R. Clark, "The Modern Integration of Research Activities with Teaching and Learning," The J. High. Educ. vol. 68, issue 3, pp. 241255, 1997.

[23] A. Jenkins, R. Breen, R. Lindsay and A. Brew, Reshaping teaching in higher education. Linking teaching with research. London: Kogan Page Limited, 2003.

[24] P. Kahn and K. O'Rourke "Understanding enquiry-based learning,” In Handbook of Enquiry \& Problem Based Learning. T. Barrett, I. Mac Labhrainn and $\mathrm{H}$. Fallon (Eds). Galway: CELT, (online) URL: http://www.nuigalway.ie/celt/pblbook/chapter1.pdf, [Accessed July 7, 2014], 2005.

[25] A. Jenkins, M. Healey and R. Zetter, Linking teaching and research in disciplines and departments. The Higher Education academy. (online), http://www.heacademy.ac.uk/assets/documents/teachingandresearch/Lin kingTeachingAndResearch_April07.pdf, [Accessed July 7, 2014], 2007.

[26] M. Healey and A. Jenkins, Developing undergraduate research and inquiry. The Higher Education Academy. (online), URL: http://www.heacademy.ac.uk/assets/documents/resources/publications/D evelopingUndergraduate_Final.pdf, [Accessed July 7, 2014], 2009.

[27] R. Barnett, "Introduction". In Reshaping the University: New Relationship between Research, Scholarship and Teaching. R. Barnett (ed.). London: Society for Research into Higher Education \& Open University Press- McGraw Hill Education, pp. 1-8, 2005.

[28] L.S. Hirsch, A. Perna, J. Carpinelli and H. Kimmel, "The Effectiveness of Undergraduate Research Programs: A Follow-up Study," 2012 IEEE Frontiers in Education Conference (FIE 2012). Proceedings of a meeting held 3-6 October 2012, Seattle, Washington, USA. Institute of Electrical and Electronics Engineers (IEEE), pp. 203-206, 2012. 
[29] D. Lopatto, "Undergraduate research experiences support science career decisions and active learning," CBE Life Sci. Educ. vol. 6, issue 4, pp. 297-306, 2007.

[30] A. Brew, "Understanding the scope of undergraduate research: a framework for curricular and pedagogical decision-making," High. Educ. vol. 66, issue 5, pp. 603-618, 2013.

[31] E. Alpay and R. Verschoor, Practices and approaches for the integration of teaching and research. Higher Education Academy. (online), URL: www.journals.heacademy.ac.uk/doi/pdf/10.11120/stem.hea.2012.029, [Accessed July 7, 2014], 2012.

[32] S. Cairncross, "Special session - enhancing graduate attributes through Research-Teaching Linkages," In 39th ASEE/IEEE Frontiers in Education Conference. Frontiers in Education Conference, 2009 (FIE '09). 39th IEEE Proceedings of the meeting held 18-21 Oct. 2009, San Antonio, TX, pp. 1 - 2, 2009.

[33] The Gwenna Moss Centre for Teaching Effectiveness, Integrating Research and Teaching. How can Research be integrated into Teaching and Learning?, University of Saskatchewan, (online), URL: http://www.usask.ca/gmcte/research-and-teaching, [Accessed July 7, 2014], 2014.

[34] ACLS Teagle Working Group in Liberal Education, Scholar-Teachers and Student Learning, Student Learning and Faculty Research: Connecting Teaching and Scholarship, American Council of Learned Societies, (online)

http://www.acls.org/uploadedFiles/Publications/Programs/ACLS

Teagle_Teacher_Scholar_White_Paper.pdf, [Accessed July 7, 2014], 2007

[35] K. Hamidreza, I. Zaleh and M.Y. Yudariah, "Supporting engineering students' thinking and creative problem solving through blended learning," Procedia - Social and Behavioral Sciences, vol. 56, pp. 117 $125,2012$.

[36] X. Li, "Learning from industry by using an inquiry based learning approach," 2013 IEEE Frontiers in Education Conference (FIE 2013). Proceedings of the meeting held 23-26 October 2013, Oklahoma City, Oklahoma, USA. Institute of Electrical and Electronics Engineers (IEEE), pp. 943-949, 2013.

[37] M.G. Yang, P. Hong and S.B. Modi, "Impact of lean manufacturing and environmental management on business performance: An empirical study of manufacturing firms," Int. J. Prod. Econ. vol. 129, issue 2, pp. 251-261, 2011.

[38] R. Shah and P.T. Ward, "Lean manufacturing: context, practice bundles, and performance,“ J. Op. Mng. vol. 21, issue 2, pp. 129-149, 2003.

[39] R. Shah and P.T. Ward, "Defining and developing measures of lean production,“ J. Op. Mng. vol. 25, issue 4, pp. 785-805, 2007.
[40] M. Holweg, "The genealogy of lean production,” J. Op. Mng. vol. 25 , issue 4, pp. 420-437, 2007.

[41] L.C. Angell and R.D. Klassen, "Integrating environmental issues into the mainstream: an agenda for research in operations management," Int. J. Op. \& Prod. Mngt., vol. 11, issue 3, pp. 63-76, 1999.

[42] C.J. Corbett and P. Keindorfer, "Environmental management and operations management: introduction to part 1 (manufacturing and ecologistics)," Prod. Op. Mng., vol. 10, issue 2, pp. 107-111, Summer 2001.

[43] R. Navarro-Antúnez, C. Vintró-Sánchez and J. Fortuny-Santos, "Environmentl management indicators in an industrial engineering school," Dyna, vol. 89, issue 2, pp. 202-210, 2014.

[44] R.M. Fisher, "Applying ISO 14001 as a business tool for campus sustainability: A case study from New Zealand,” Int. J. Sustainability in Higher Education, vol.4, issue 2, pp. 138-150, 2003.

[45] S.H. Creighton, Greening the Ivory Tower: Improving the Environmental Track Record of Universities, Colleges and Other Institutions. Cambridge: MIT Press, 1999.

[46] United Nations Educational, Scientific and Cultural Organization, Policy Dialogue 1: ESD and development policy: education and the eearch for a sustainable future. Paris: UNESCO (online) URL: http://unesdoc.unesco.org/images/0017/001791/179121e.pdf [Accessed April 21, 2014].

[47] R. Van Berkel, "Integrating the environmental and sustainable development agendas into minerals education," J. Cleaner Production, vol. 8, issue 5, pp. 413-423, October, 2000.

[48] D. Ferrer-Balas, "Global environmental planning at the Technical University of Catalonia," Int. J. of Sustainability in Higher Education. vol. 5, issue 1, pp. 48-62, 2004.

[49] T.S.A. Wright, "Definitions and frameworks for environmental sustainability in higher education,", Int. J. of Sustainability in Higher Education, vol. 3, issue 3, pp. 203-220, 2002.

[50] K.R. Leitch, C. Koop, M. Messer and A. Payne, "Green construction in civil engineering instruction," 2013 IEEE Frontiers in Education Conference (FIE 2013). Proceedings of the meeting held 23-26 October 2013, Oklahoma City, Oklahoma, USA. Institute of Electrical and Electronics Engineers (IEEE), pp. 24-28, 2013.

[51] S. Winn, "Learning by doing: Teaching research methods through student participation in a commissioned research project," Studies in Higher Education, vol. 20, issue 2, pp. 203-214, 1995.

[52] T. Ohno, Toyota Production System: Beyond Large-Scale Production. Portland: Productivity Press. 1988.

[53] R. Neumann, “The Teaching-Research Nexus: Applying a framework to university students' learning experiences," European Journal of Education, vol. 29, issue 3, pp. 323-339, 1994. 